\title{
THE VIRTUAL RECONSTRUCTION OF AN EARLY MEDIEVAL FOLDED SICKLE FROM NASIELSK
}

\begin{abstract}
During archaeological research carried out in Nasielsk, Poland in 2006 by Dr. M. Błoński, a fragment of an ornamented sickle handle was found. It most likely dates to the $2^{\text {nd }}$ half of the $10^{\text {th }}$ century, but may have been made as late as the mid-1 $11^{\text {th }}$ century. The sickle with a movable blade is interpreted as belonging to the equipment of an elite horse warrior. Many finds of this type known from unusual medieval deposits suggests their special, symbolic meaning and a connection with the military sphere. The artefact is ornamented with a variation of the Borre ring-chain pattern - specifically, the Pomeranian school of Scandinavian-Insular decoration. The origins of this style emerged in the 10th century with the combining of Celtic, English, and Scandinavian elements - and it was developed intensively in western Pomerania. The artefact from Nasielsk has only partially survived. The preserved fragment of the handle was 3D scanned using a structured light scanner and photogrammetry software. In order to make a 3D reconstruction, documentation of a second, not available fragment was also used. Moreover, certain analogies from early medieval folded sickles were analyzed. The most important questions concerned the shape of the blade, the continuation of the ornament, its design features, and a proper visualization of the reconstruction.
\end{abstract}

KEY WORDS: 3D reconstruction, 3D scan, Medieval, Borre, sickle

During archaeological research conducted in 2006 in Nasielsk, northern Mazowsze, by Dr. M. Błoński, a fragment of an object made of antler was found (Błoński 2013; Błoński 2018, 106108, Fig. 100). Although only partially preserved (Fig. 1), its telltale shape allowed its function to be identified as a folding sickle handle. The visible ornament, a modified version of a ring-chain pattern, links it with the area of Scandinavian influence around the Baltic Sea. The second part of the same handle, found to be illegally kept by unauthorized persons, is known from a photograph (Fig. 2). The application of a variety of research methods - anal- ysis of the form of the preserved fragment and the part reconstructed from the photo; reference to existing analogies; and the use of 3D digitalization and modelling - allowed a reconstruction of the possible original appearance of this artefact.

The Nasielsk stronghold was located in the valley of the Nasielna river. It has a diameter of circa $80 \mathrm{~m}$ and its earthwork walls are preserved up to a height of $2.5 \mathrm{~m}$. The time of its establishment was specified to the beginning of the 860 s by means of dendrochronological analysis of the remains of the rampart. From archaeological excavations and written sources, we know that it was in use until the 


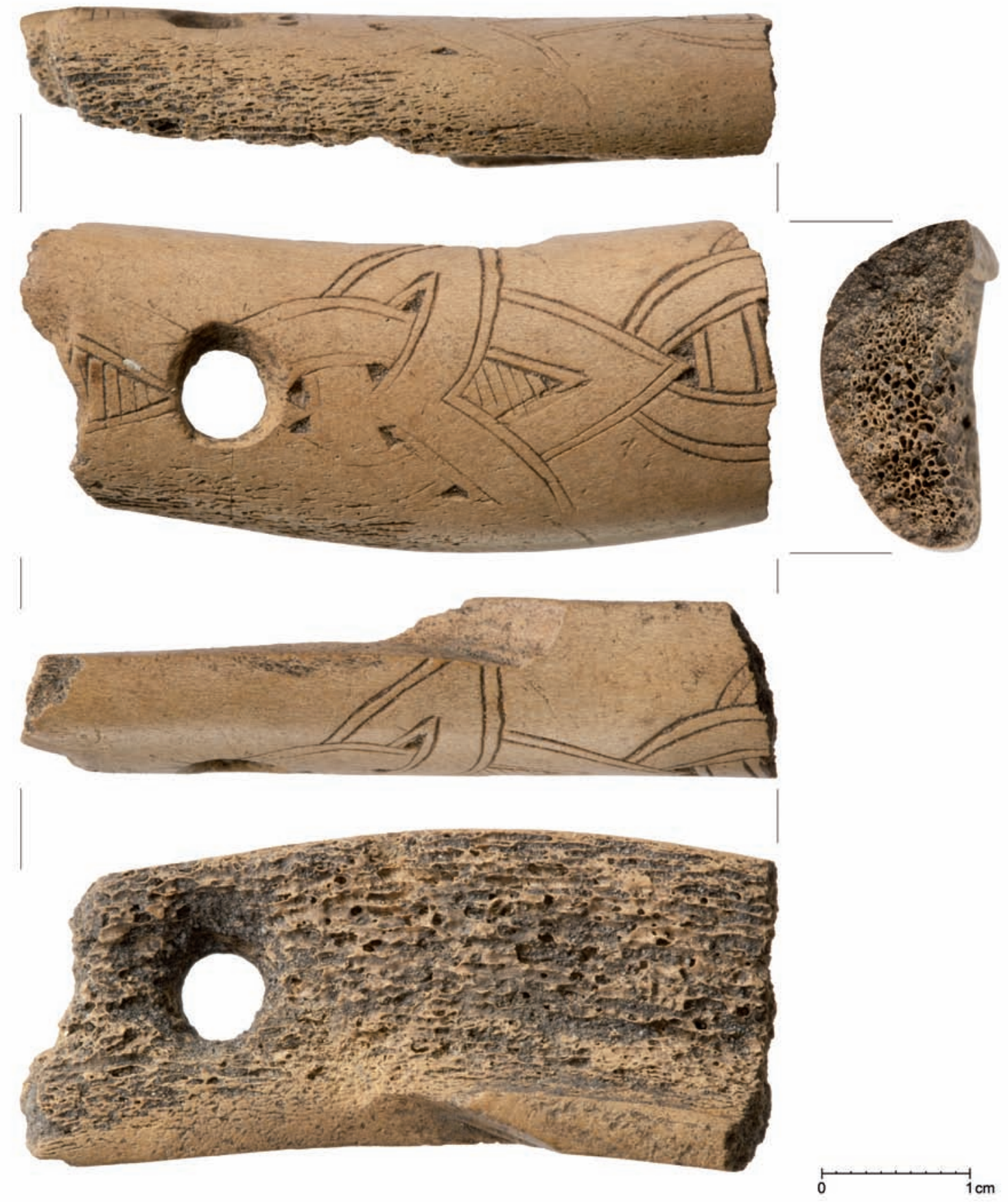

Fig. 1. Photograph of the preserved part of the sickle handle

second half of the 13th century, when it was abandoned (Błoński 2013; 2015; 2018).

The artefact made of antler was found in a settlement located just several dozen metres away from the Nasielsk stronghold. The sickle handle fragment was deposited in the fill of a ditch with numerous fragments of early medieval pottery. The researcher and author of the Nasielsk stronghold excavations dated the artefact to the $2^{\text {nd }}$ half of the $10^{\text {th }}$ century, possibly up to the first half of $11^{\text {th }}$ century (Błoński 2013, 315, 317-318; Błoński 2018, 109).

The preserved handle fragment is $5.1 \mathrm{~cm}$ long, maximally $2.2 \mathrm{~cm}$ wide, and $1 \mathrm{~cm}$ thick. The conspicuous arched shape is characteristic for sickles. To produce handles, parts of antlers with a natural, regular arch were used. Along their surface, on the outer part of the arch, a cut was made to accommodate the blade. The slab on the outside is even, 


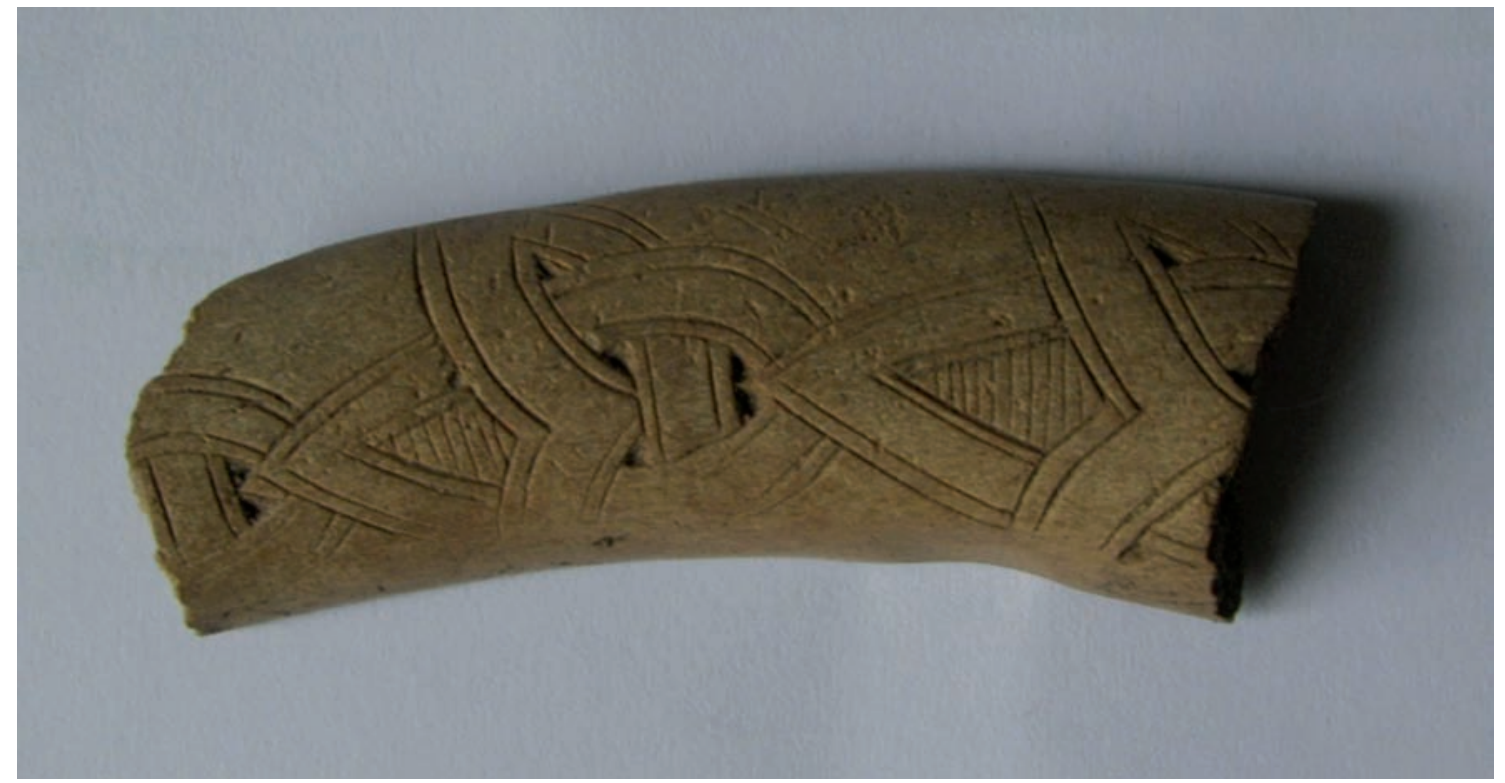

Fig. 2. A part of the same handle, known only from a photograph

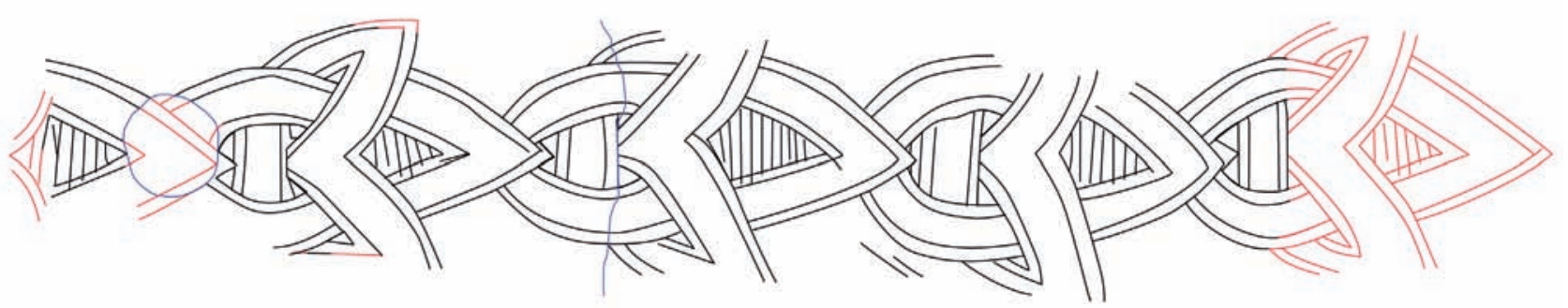

Fig. 3. Drawing of the ornament (black - preserved fragments; red - reconstructed fragments; blue - a hole and a crack)

smoothly polished, and made to shine. It has no traces of having been planed, which indicates an intentional, thorough polishing of the compact bone surface. On the inner side, the cancellous bone is visible in the place where the analogical fragment covering the blade was broken off. In the same place, it is possible to discern an intentionally profiled fragment of compact bone with a smooth surface. This is probably the partition abutting to the blade's beginning that blocked it into position after opening. The handle was broken off on both sides, but the lower part with a hole (5-6 $\mathrm{mm}$ in diameter) must have been near the original end. The hole contained a rivet upon which the moveable blade was fitted.

The surface of the handle displays an evident ornament that can be reconstructed further on the basis of the photograph of the missing fragment (Fig. 3). The visible reminiscence of ring-chain pattern can be identified as a variety of the Borre type. The ornament was not carved in a particularly precise manner - some lines are crossed, some are carved accidentally, and near the borders the motif is unfinished. Although the artefact was certainly a valuable object belonging to an elite member of the local community, the symmetry and precision of the ornament was not particularly important, whether for its producer or its user.

Folded sickles in archaeological studies have usually been treated as a marginal part of the subject of agricultural tools. They have movable blades placed in antler handles. The blades have S-shape ends that hide inside the handle when open. At the end there were very often iron rings, designed to hang the object on a belt or saddle (Stattler 1962, 331) and possibly to block the open sickle.

After the Second World War, Z. Rajewski (1948) described nine known finds of this type from 
Europe and dated them to the period of the $10^{\text {th }}-12^{\text {th }}$ centuries. In a short study of Slavic harvest tools, M. Beranová $(1957,103$, Obr. I) proposed their classification and defined movable sickles as type C. In the opinion of Z. Podwińska (1954, 418-419), long, curved sickle-knives (koser) were a significant type of tool for primitive agriculture, fire-fallow cultivation, and were intended to cut small branches. As she noted, iconography suggests that later on folded sickles could be useful for viticulture.

In the opinion of M. Eliade (1966, 325-326), agriculture has a primarily ritual character in all agricultural societies, even contemporary ones, because the farmer by his activity enters the space of the sacrum and becomes a part of it. The significant impact of archaic agricultural belief systems on Slavic mythology was emphasized by A. Gieysztor (2006, 204). In traditional Slavic folk beliefs, iron tools had a special symbolic meaning and it was believed that they had an apotropaic function. Sharp iron objects of everyday use, like knives, awls or sickles, were able to protect people (especially the weak, like pregnant women and young or sick children) from demonic influences (Moszyński 1934, 309-310). They could also be used to cast spells (Fisher 1926, 132).

W. Chudziak remarked that many unusual medieval deposits with sickles suggest their special, symbolic meaning $(2005,202)$. He noted that many of them were found in a military context, near big deposits of weapons, and especially near bridges. It is more probable that they may have functioned as a sacrifice and could be thrown into water close to the shore of lakes, where in the symbolic meaning the danger of demonic influence was the strongest (Chudziak 2005, 212-214).

On the island in the village of Żóte, the skulls of a mare and a sheep were identified together with a ceramic vessel and a sickle: this was interpreted as a sacrifice (Chudziak 2009, 57). On the other hand, in the Carpathian Basin and on the central Danube, there was a widespread custom, also present in Poland, to equip the deceased with a sickle. In this case, the practice was likely to prevent the deceased from interfering in the world of the living (Janowski, Kurasiński 2010).

Three folded scythes were found in Veliky Novgorod dated to the $13^{\text {th }}, 14^{\text {th }}$, and $15^{\text {th }}$ centuries. They were significantly longer than the aforementioned early medieval ones. The fully preserved one is $42 \mathrm{~cm}$ long and its blade is placed with a rivet between the two flat iron pieces of the handle, probably originally covered by wood. In the opinion of B. A. Kolchin $(1959,74)$, these scythes were elements of equipment carried by horse riders or coachmen and were intended for preparing fodder.

W. Hensel (1987, 65-66) remarked that early medieval folding sickles could be an element of horse riders' equipment. Z. Podwińska $(1954,421)$ noted that in the Saschenspiegel, a law book of the Holy Roman Empire from the $14^{\text {th }}$ century, there is an image of a horse rider cutting grass. E. Stattler (1962) had accepted and developed this conception. In her opinion, such ornamented folding sicklesknives were used to emphasize the elite status of the rider warrior, and were used in military campaigns, having descended from tools used to cut horse fodder. The researcher remarked that in ancient mythology a sickle was sometimes mentioned as a weapon and had a strong relationship with the warrior profession, while having a religious function as well. It was also noted by Saxo Grammaticus that in early medieval times, sickles could be used for military purposes (Niesiołowska-Wędzka 1975, 173).

Folding sickles in early medieval times could still be universal agricultural tools, but the valuable ones, with carefully finished decorations, were certainly reserved for a society's elite. As suggested by many early medieval sickle finds, they also could have a special apotropaic function.

The visible ring-chain ornament on the handle from Nasielsk was linked by the excavator (Błoński 2013, 316-317; Błoński 2018, 106-108) with the local school of the Borre style, defined by W. Duczko (2000, 28-29) as the Pomeranian school of Scandinavian-Insular decoration. This style emerged in the $10^{\text {th }}$ century principally under the influence of populations of Scandinavian (Norwegian) descent that came to north-western England indirectly, via Ireland. They were under the plain influence of Irish culture, while also standing apart from the mainstream Scandinavian art. Some examples of this style from the British Isles include the cross from Gosforth in Cumbria and the Gauta cross from the Isle of Man (Foote, Wilson 1975, 288-289, Fig. 48).

The literature underlines the strong links between artefacts from the British Isles and the Pomeranian ornamental style which display strong Scandinavian influences (Chudziak 2013, 169171). The complicated issue of the spread of 

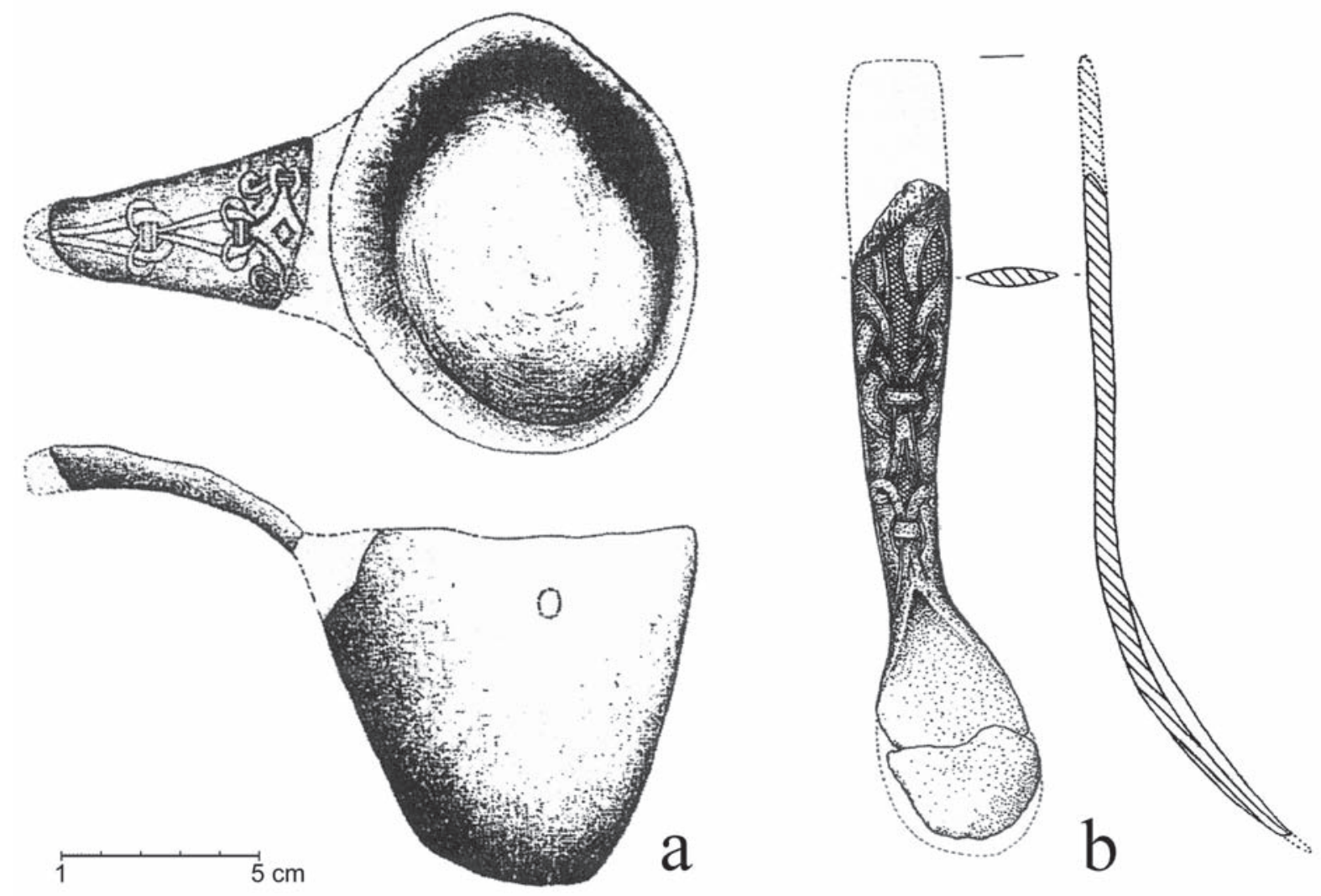

Fig. 4. Wooden spoons with Borre style decoration from Wolin: a) Wolin-Old Town (Stare Miasto), Site 1 (Filipowiak 2004, Fig. 13, drawn by M. Jusza); b) Wolin-Gardens (Ogrody), Site 4

(Filipowiak 2004, Fig. 14, according to B. Stanisławski)

"insular" ornamentation in the Baltic Sea area was more widely referred to by W. Chudziak and R. Kaźmierczak in the context of a rich collection of ornamented wooden artefacts from Żółte. According to their proposed classification of ornamental motifs (Chudziak, Kaźmierczak 2013, 12-13, Fig. $8: 2$ ), the ornamentation of the sickle from Nasielsk should be classified as knot type 2, although in the ornamentation of objects from Żółte there are no strict analogies for the discussed artefact. The researchers also pointed out that in the $11^{\text {th }}$ and $12^{\text {th }}$ centuries this style was still developing in a reduced form, also outside the borders of western Pomerania (Chudziak, Kaźmierczak 2013, 25-27).

This type of interlaced ornamentation is very well represented by the artefacts made of antler, bone, and wood from early medieval Wolin. W. Filipowiak $(2004,62)$ connected that ornament type with Scandinavian traits and pointed out that some braid decorations has analogies in finds from England and Ireland. It is significant that in Wolin fragments of fabric specific to those known from
Scotland and Ireland were found (Maik 1986, 64). B. Stanisławski (2013, 202-204; 2014, 318-319, 325-330) considered that these ornamented artefacts from Wolin (belonging principally to the period between the final third of the $10^{\text {th }} \mathrm{c}$. and the first half of the $11^{\text {th }} \mathrm{c}$.) should be associated with the presence of newcomers from the north. In particular, some wooden spoons were decorated with a motif similar to the Nasielsk artefact. They were dated by dendrochronological method to the period from 965/966 to the middle of the $11^{\text {th }}$ century (Fig. 4:a) and to the second half of the $10^{\text {th }}$ century (Fig. 4:b). According to the classification of ornamental motifs proposed by W. Chudziak and R. Kaźmierczak (2013, 12-13, Fig. 8:2) for the large collection of artefacts from Żółte, the ornament of the sickle from Nasielsk should be classified as a knot type 2, although there are no close analogies for it.

There are two analogies for the Nasielsk artefact from Gniezno. Both have an ornament of transverse lines and they are quite similar to one another. The first one (Rajewski 1936; Sawicki 2018, 142, 


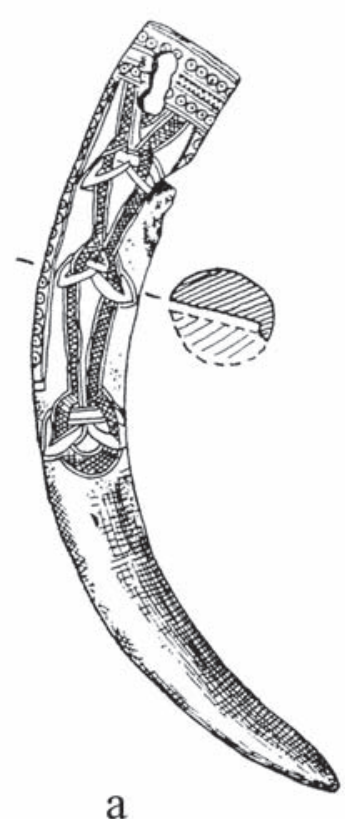

a
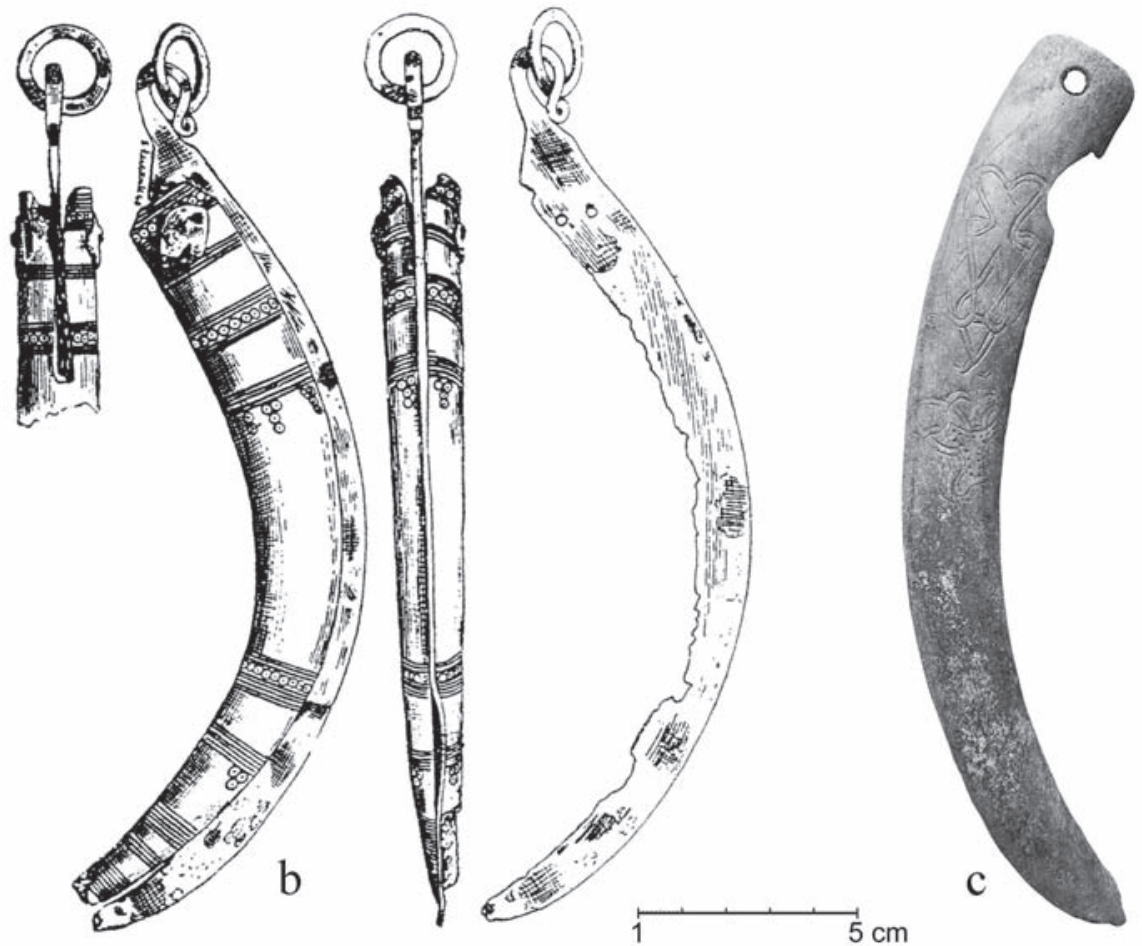

Fig. 5. Folded sickles: a) Biskupin (Rajewski 1948, 551-552, Ryc. 1:1); b) Gniezno-Góra Lecha, site 16 (Rajewski 1948, 551-552, Ryc. 3); c) Śródka in Poznań (Pawlak, Wesołowska 2014, 112, Fig. 2)

Fig. IX.38), from Gniezno-Góra Lecha (site 16), is fully preserved and still has the iron ring designed to hang it (Fig. 5:b). The second one, from site 22 (Chrzest - św. Wojciech - Polska, 179, 237), has a clearly visible serration on one-centimetre-long blade fragments, alternating with non-serrated ones (Fig. 6).

A motif quite similar to the one on the Nasielsk sickle, but in a more developed form, is visible on a handle found in 1939 in Biskupin (Fig. 5:a). Another one (Fig. 4:c) is known from the settlement part of the Sródka site in Poznań (Pawlak and Wesołowska 2014, 112, Fig. 2). The site is dated to the $10^{\text {th }}$ century and the settlement was in use before a cemetery was established there, one that functioned from the turn of the $10^{\text {th }}$ and the $11^{\text {th }}$ century to the middle of the $12^{\text {th }}$ century (Pawlak 1988).

Another relatively well-preserved folding sickle was found in Lake Lednica (Kola and Wilke 1989, 91, Fig. 12:3; Górecki 1998, 41). More examples of such artefacts from Poland are known from Santok, Stargard, unspecified places in Śląsk (Silesia) and Pomorze (Pomerania) (Rajewski 1948, 553) and from Pień (Drozd, Janowski 2005, 151, Fig. 6:a).
As mentioned earlier, in Veliky Novgorod, three folding scythes dated to the $13^{\text {th }}, 14^{\text {th }}$, and $15^{\text {th }}$ centuries were discovered. They are more recent and larger than the other here described, but are using the same technological solution to combine movable blades with handles. They also have the same S-shape end of blades (Kolchin 1959, 73-75). One of them, with an iron handle, is well preserved (Kolchin 1959, 73-75, Ris. 61:1).

The specific qualities of antler as a craft material have significant implications for the form of the artefact and, therefore, require a short explanation. Antlers were commonly available in Central Europe and could be easily acquired during the shedding season (February to April for deer, but principally March), without the need for hunting. Although the introduction of royal privilege laws limiting the rights to hunt is associated with the end of the early medieval period, it cannot be excluded that certain limitations in this matter had appeared already in the $11^{\text {th }}$ century (Cnotliwy 1973, 26).

The popularity of antler for the production of (among other things) knife and sword handles, containers, pins, and ornaments stemmed mainly from its durability. Additionally, the polished surface 


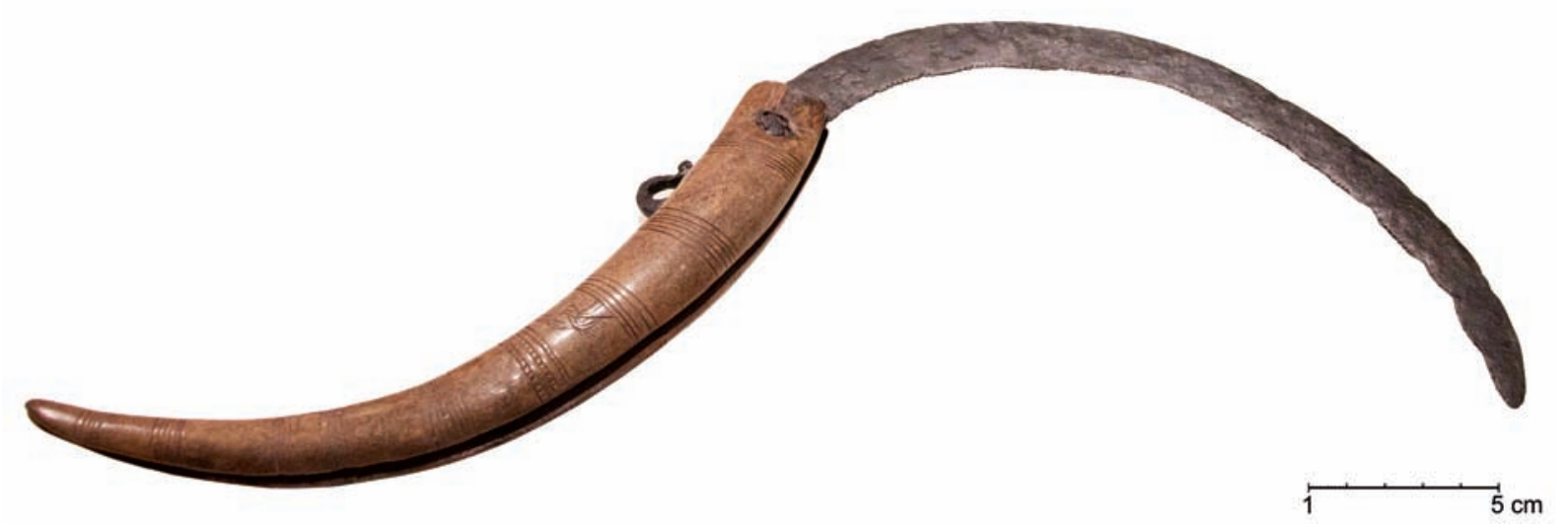

Fig. 6. Folded sickle from Gniezno, Site 22

of the compact bone gains an elegant gloss and is perfect for the application of ornaments. The inner structure of antler does not differ much from bone structure, however, it has a higher percentage of organic components: in bones, it amounts to $30-35 \%$, whereas it is about $44 \%$ in antlers. Such composition affects directly the material's physical properties, which is why antler is not as hard as bone, but has more flexibility. The main structure of the antler includes the compact bone (substantia compacta) forming a hard wall, with the lamellar cancellous bone (substantia spongiosa) within. The compact bone is covered with irregular bony protuberances of a darker colour, called "pearling" (Drzewicz 2004, 11-14).

As antler is a hard material, researchers agree it always needs to be mollified before processing. The first attempts in experimental archaeology in this matter began in Poland before World War II (Rajewski 1950, 178-179; Malinowski 1990, 221-222). Later on, the subject was thoroughly researched, inlcuding by K. Żurowski (1974) and G. Osipowicz (2005, 22-30). E. Cnotliwy (1973, 40-42) based his research on archaeological finds from the Middle Ages. The research confirmed that the simplest and most ethnographically confirmed method of mollifying bones and antlers is boiling them in water. As a result, the outer layer of antler becomes easier to process for a short period of time (about 2 minutes according to the author's experience), after which it is necessary to put the object into boiling water again. Another efficient method is also prolonged soaking in water, although the author's experience suggests it should last no longer than 3 months, since after that time the material becomes dramati- cally more fragile, rendering it unusable. This is the effect of washing out the organic compounds, which happens also when the material is boiled for too long (Osipowicz 2005, 33). Another way to soften antler is to leave it for some time in an acidic environment, such as chopped dock leaves, sour milk, or sauerkraut. This method is based on a partial removal of inorganic compounds (minerals, especially calcium phosphate).

The basic shaping and removal of the irregular outer layer of antler was done though cutting and planing. A variety of iron tools were used for this purpose, including specialized ones, such as compasses to create ornaments (Cnotliwy 1973, 27-40). The surface was often polished. To make the ornament stand out visually, the lines could be filled with some black filler such as beeswax with coal.

As technological research has proved, early medieval sickle blades were very often forged from hardened metal. Some of them were carburized and some were made of combined iron and steel parts (Piaskowski 1959, 38-43; Kolchin 1959, 71). Some sickles, like the modern ones, had serration on fragments of the blade (Fig. 6).

The initial work was to provide a photographic documentation of the artefact. Then, a digital reconstruction was produced. Both scanning in white structural light and the photogrammetric software method were used in order to choose for further works the one resulting in a higher quality $3 \mathrm{D}$ model. A description of both methods was included in a previous publication (Osiadacz 2017, 243).

The scanner used for digitization was a Smarttech archeo 5MPix LED device. It has a constant measurement volume of $300 \times 210$ x $200 \mathrm{~mm}$. 


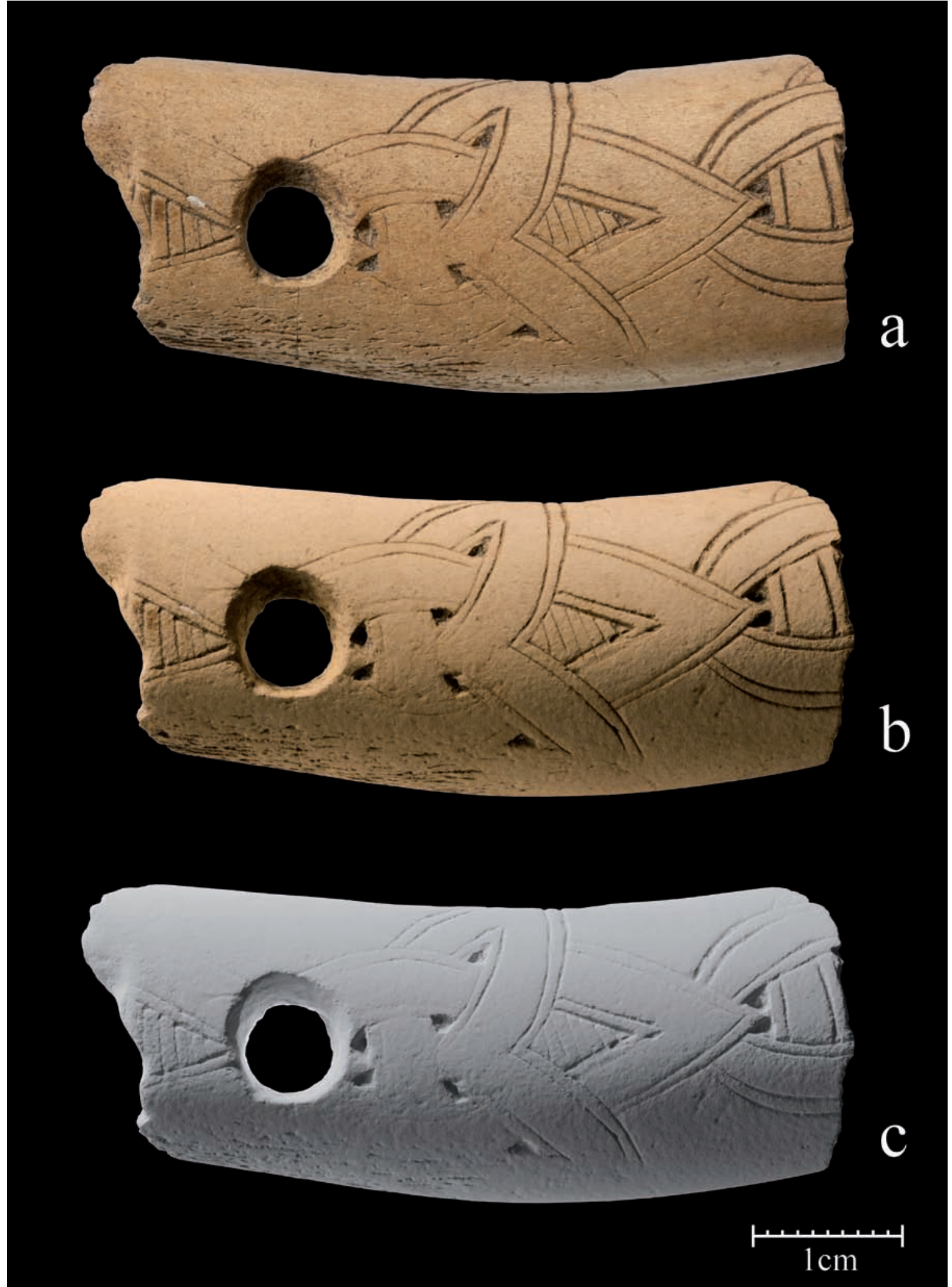

Fig. 7. Sickle handle from Nasielsk: a - photograph; b, $\mathrm{c}-3 \mathrm{D}$ model created with Reality Capture software, rendered in Blender software $(b-$ render with texture; $c$ - render without texture)

The apparatus provides high exactitude (the maximum uncertainty of the measurement, understood as acceptable error, is $0.04 \mathrm{~mm}$ ) and definition, but the scanned artefact took only a minor part of the volume; moreover, the available definition spectrum was not fully utilised. In consequence, the detail 


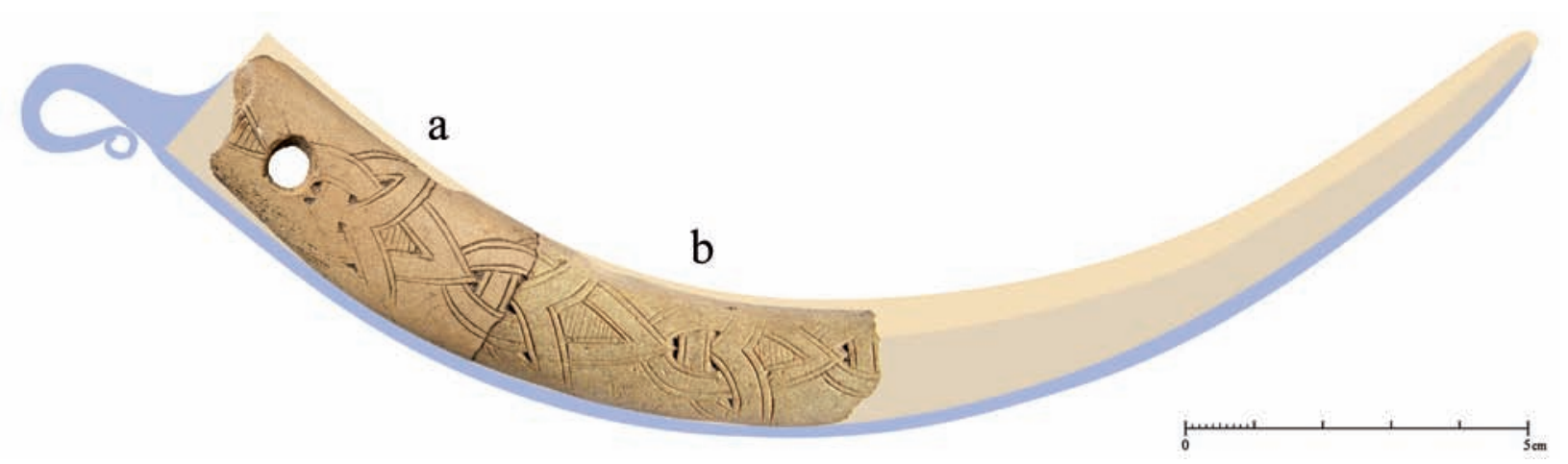

Fig. 8. Reconstruction of the sickle in side projection, with the preserved part of the handle (a) and with the fragment known from a photograph (b)

level of the obtained 3D model, counting 289000 polygons, was not sufficiently high to reconstruct the shallowly engraved ornaments of the object.

As an alternative scanning method, the photogrammetric Reality Capture software was applied. The use of 213 photographs with $16.6 \mathrm{mPix}$ definition made with Canon EOS 1 Ds mark 2 camera allowed the generation of a model consisting of 9.6 million polygons, with the ornament now clearly visible (Fig. 7).

The first step in the reconstruction was to recreate the shape of the artefact from a side projection (Fig. 8). The combined photographs of the two fragments (there is no doubt that one is the continuation of the other) display a little above $10 \mathrm{~cm}$ of the object's length. Among the analyzed analogies with a similar ornamental motif, the shortest sickle handle from Biskupin was $18 \mathrm{~cm}$ long, the find from Śródka was $20 \mathrm{~cm}$, and the longest, from Gniezno (site 16) was $28.4 \mathrm{~cm}$. Additionally, all the known analogies were broader than the Nasielsk artefact. According to those measurements and the arching of the Nasielsk sickle, its estimated length was about $20 \mathrm{~cm}$.

The form of the blade has been entirely reconstructed according to analogies. The finding from Gniezno (site 22) was very helpful because of its well preserved serration on one-centimetrelong blade fragments, alternating with non-serrated ones. The hole for the rivet in the Nasielsk artefact is $1 \mathrm{~cm}$ from the lower, broken part of the object, and the point of the breakage appears close to the original lower edge.

As mentioned earlier, the preserved fragment had a polished partition on the internal part that touched the blade, most probably serving to block the blade after opening it. Additionally, the same function could be fulfilled by an iron ring, which also allowed the sickle to be hung. The rivet has been reconstructed as made of iron with an iron plate nub, similarly to both of the Gniezno fragments and an artefact from Ostrów Lednicki.

The shape of the sickle was modelled initially with Blender software. The handle model was created directly on the fragment's scan, imported into the project in order to keep its exact shape.

As a second step, the resolution of the handle model was increased up to 11.4 million points and the ornament was applied in ZBrush software. The known preserved part, which was the basis, was extended for a little more than half of the artefact's length, as in the analogical finds from Biskupin or Poznan. There was an attempt to keep the style of the ornament, which was neither fully regular nor symmetrical and included some craftsman's mistakes. Subsequently, the Substance Painter software was applied for materials and creating textures. This allowed us to show the ornament and specific visual features - like roughness, gloss, and small surface defects characteristic for antler and iron - on a version of the model with a relatively simple geometry (about 120 thousand points). The details of the surface geometry can be also imitated by functions of the rendering software, resulting in a smaller file size of the model. This in turn facilitates making video animations and allows us to present the effects of the work in interactive forms on the web.

The preserved fragment of the handle is light beige and shows many surface defects resulting from its prolonged deposition in soil. The hard, external part of antler (compact bone) is usually nearly white after mechanical treatment and it is possi- 


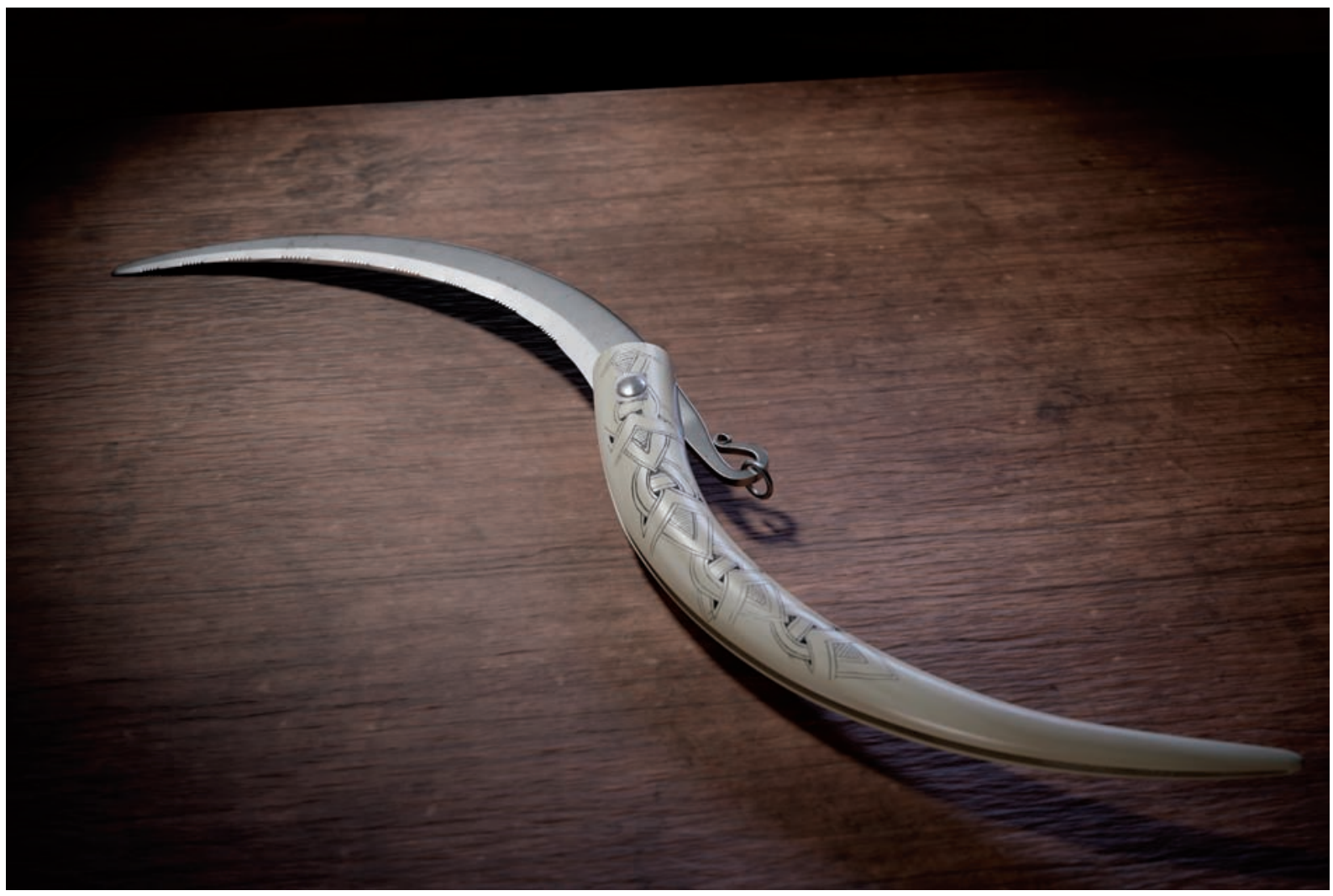

Fig. 9. 3D reconstruction of the original appearance of the Nasielsk sickle

ble to obtain a very smooth surface with high gloss. The folded sickle from Nasielsk was an elite object and it is probable that it was carefully finished. For this reason, the reconstruction was completed with applying the appropriate colour and texture for such effect (Fig. 9). In order to present the work results, a short animation was created.

The reconstruction of the original appearance of the object is based principally on analogies and so it is admittedly hypothetical. According to Article 7 of the London Charter ("Charter for the Protection and Management of the Archaeological Heritage" 1990), a reconstruction in archaeology has two main functions: scientific experiment and interpretation. The majority of digital reconstructions of monuments serve the latter function. The use of the original, scanned fragment in the recon- struction, according to the division proposed by M. Forte $(2014,116)$ allows this work to be included in the field of cyberarchaeology, which, in contrast to virtual archaeology, from the beginning operates with digital data, and not with digitized analogue data.

However, any virtual reconstruction of an object requires defining characteristics that are not fully supported by data, and thus it needs to be supported by analogies. In the case of a visual reconstruction, it is not possible to omit selected elements that are not sufficiently documented. Thus, the virtual reconstruction work is always subject to the risk of error, and the basis for the scientific credibility of the process is a description of the method used and reference to sources. 


\section{BIBLIOGRAPHY}

Beranová M. (1957). Slovanské žňové nástroje v 6. - 12. století. Památky Archeologické, 48 (1), 99-117.

Błoński M. (2013). Antler sickle handle from Nasielsk. An example of the Pomeranian school of ScandinavianInsular ornament from Mazovia. In: S. Moździoch et al. (ed.), Scandinavian Culture in Medieval Poland (315-321). Wrocław: Institute of Archaeology and Ethnology of Polish Academy of Sciences.

Błoński M. (2015). Dendrochronologia o początkach grodu w Nasielsku. In: M. Krasna-Korycińska (ed.), Grody średniowiecznego Mazowsza. Księga poświęcona pamięci Marka Dulinicza (237-242). Warszawa, Zielona Góra: Wydawnictwo Fundacji Archeologicznej IAE PAN.

Błoński M. (2018). Nasielsk we wczesnym średniowieczu. Warszawa: Wydawnictwo Instytutu Archeologii i Etnologii PAN.

"Charter for the Protection and Management of the Archaeological Heritage". (1990). https://www.icomos.org/ charters/arch_e.pdf.

Chrzest-św. Wojciech-Polska. Dziedzictwo średniowiecznego Gniezna. Katalog wystawy. (2016). Gniezno: Muzeum Początków Państwa Polskiego w Gnieźnie.

Chudziak W. (2005). Z badań nad funkcją sierpów i półkosków na ziemiach słowiańskich we wczesnym średniowieczu. Archaeologia Historica Polona, 15/2, 201-219.

Chudziak W. (2009). Wyspa w Żółtym na Jeziorze Zarańskim - na pograniczu rzeczywistości i transcendencji. In: T. Sawicki (ed.), Studia nad dawna Polska. Tom 2 (47-70). Gniezno: Muzeum Początków Państwa Polskiego.

Chudziak W. (2013). Remarks on particular material traces of Scandinavian culture in Pomerania. In: S. Moździoch et al. (eds), Scandinavian Culture in Medieval Poland (151-178). Wrocław: Institute of Archaeology and Etnology of Polish Academy of Sciences.

Chudziak W., Kaźmierczak R. (2013). Zdobnictwo przedmiotów drewnianych z Żółtego na Pomorzu Zachodnim jako przykład tzw. pomorskiej szkoły ornamentyki skandynawsko-insularnej. In: J. Chudziakowa (ed.), Archaeologia Historica Polona, tom 21 (7-30). Toruń: Uniwersytet Mikołaja Kopernika, Uniwersyteckie Centrum Archeologii Średniowiecza i Nowożytności.

Cnotliwy E. (1973). Rzemiosło rogownicze na Pomorzu wczesnośredniowiecznym. Wrocław, Warszawa, Kraków, Gdańsk: Zakład Narodowy Imienia Ossolińskich, Wydawnictwo Polskiej Akademii Nauk.
Drozd A., Janowski A. (2005). Grodzisko późnośredniowieczne (stan. 1) i osada wczesnośredniowieczna (stan. 2) w miejscowości Pień, gm. Dąbrowa Chełmińska, województwo kujawsko-pomorskie. In: H. Paner, M. Fudziński (eds), XIV Sesja Pomorzoznawcza. Od wczesnego średniowiecza do czasów nowożytnych (147-155). Gdańsk: Muzeum Archeologiczne w Gdańsku.

Drzewicz A. (2004). Wyroby z kości i poroża z osiedla obronnego ludności kultury tużyckiej w Biskupinie. Warszawa: Wydawnictwo Naukowe Semper.

Duczko W. (2000). Obecność skandynawska na Pomorzu i słowiańska w Skandynawii we wczesnym średniowieczu. In: L. Leciejewicz, M. Rębkowski (eds), Salsa Cholbergiensis. Kołobrzeg w średniowieczu (2343). Kołobrzeg: Wydawnictwo Le Petit Cafe.

Eliade M. (1966). Traktat o historii religii. Kraków: Książka i Wiedza.

Filipowiak W. (2004). Some aspects of the development of Wolin in the 8th - 11th centuries in the light of the results of new researches. In: P. Urbańczyk (ed.), Polish Lands at the Turn of the First and the Second Millennia (47-74). Warsaw: Institute of Archaeology and Etnology of Polish Academy of Sciences.

Fisher A. (1926). Lud polski. Podręcznik etnografji Polski. Lwów-Warszawa-Kraków: Wydawnictwo Zakładu Narodowego im. Ossolińskich.

Foote P.G., Wilson D.M. (1975). Wikingowie. Warszawa: Państwowy Instytut Wydawniczy.

Forte M. (2014). Virtual reality, cyberarchaeology, teleimmersive archaeology. In: F. Remondino, S. Campana (eds), 3D Recording and Modelling in Archaeology and Cultural Heritage (113-127). Oxford: Publishers of British Archaeological Reports, BAR International Series.

Gieysztor A. (2006). Mitologia Słowian. Warszawa: Wydawnictwa Uniwersytetu Warszawskiego.

Górecki J. (1998). Kultowo rezydencjonalny ośrodek pierwszych Piastów na Ostrowie Lednickim. In: T. Janiak, D. Stryniak (eds), Civitates Principales. Wybrane ośrodki władzy w Polsce wczesnośredniowiecznej. Katalog wystawy (35-44). Gniezno: Muzeum Początków Państwa Polskiego.

Janowski A., Kurasiński T. (2010). Rolnik, wojownik czy „odmieniec”? Próba interpretacji obecności sierpów w grobach wczesnośredniowiecznych na terenie ziem polskich. In: W. Świętosławski (ed.), Wymiary inności. Nietypowe zjawiska $w$ obrzędowości pogrzebowej od 
pradziejów po czasy nowożytne (79-95). Łódź: Łódzkie Towarzystwo Naukowe.

Kola A., Wilke G. (1989). Sprawozdanie z archeologicznych badań podwodnych reliktów wczesnośredniowiecznego mostu ,poznańskiego” (Rybitwy, stan. 3a) w Jeziorze Lednickim w latach 1986-1987. Studia Lednickie, 1, 77-97.

Kolchin B.A. (1959). Zhelezoobrabatyvayushchee remeslo Novgoroda Velikogo. Materialy i issledovaniya po arkheologii SSSR, 65, 7-10.

Malinowski T. (1990). Eksperymenty archeologiczne w Polsce. Archeologia Polski, 35(2), 215-239.

Niesiołowska-Wędzka A. (1975). Sierpy. In: G. Labuda, Z. Stieber (eds), Słownik Starożytności Słowiańskich (173-174), Wrocław.

Osiadacz M. (2017). Wybrane techniki dokumentacji, rekonstrukcji i wizualizacji 3D na przykładzie zbioru neolitycznych zabytków z terenu Małopolski. Raport, $12,239-250$.

Osipowicz G. (2005). Metody rozmiękczania kości i poroża $w$ epoce kamienia $w$ świetle doświadczeń archeologicznych oraz analiz traseologicznych. Torun: Wydawnictwo Adam Marszałek.

Pawlak P., Wesołowska P. (2014). Nowe badania archeologiczne na Śródce w Poznaniu. Ecclesia. Studia z Dziejów Wielkopolski, 9, 109-126.

Piaskowski J. (1959). Metaloznawcze badania wczesnośredniowiecznych wyrobów żelaznych z Łęczycy, Czerchowa i Buczka. In: Pazdur J. (ed.), Studia z dziejów górnictwa i hutnictwa (7-101). Warszawa-Wrocław: Zakład Narodowy Imienia Ossolińskich, Wydawnictwo Polskiej Akademii Nauk.

Podwińska Z. (1954). Narzędzia uprawy roli w Polsce w okresie wczesnośredniowiecznym. Zarys problema- tyki. Kwartalnik Historii Kultury Materialnej, 2(3), 388-423.

Rajewski Z. (1936). Kozik wczesnopiastowski znaleziony w Gnieźnie. Z Otchłani Wieków, 11 (12), 145-147.

Rajewski Z.A. (1948). Sierpy składane z okresu wczesnodziejowego. Slavia Antiqua, 1, 551-559.

Rajewski Z.A. (1950). Przedmioty z rogu i kości i obróbka obu tych surowców w grodach „łużyckich” z wczesnego okresu żelaznego. In: J. Kostrzewski (ed.), III Sprawozdanie z prac wykopaliskowych $w$ Biskupinie w pow. żnińskim $w$ latach 1938-1939 oraz 1946-1948 (171-185). Poznań: Polskie Towarzystwo Prehistoryczne.

Sawicki T. (2018). Powstanie i rozwój wczesnośredniowiecznego zespołu grodowego. In: P. Urbańczyk (ed.), Gniezno. Wczesnośredniowieczny zespót grodowy (119-147). Warszawa: Instytut Archeologii i Etnologii Polskiej Akademii Nauk.

Stanisławski B. (2013). Norse culture in Wolin-Jómsborg. In: S. Moździoch et al. (eds), Scandinavian Culture in Medieval Poland (193-246). Wrocław: Institute of Archaeology and Etnology of Polish Academy of Sciences.

Stanisławski B. (2014). Jómsvikinga saga w świetle źródeł archeologicznych. In: B. Stanisławski, W. Filipowiak (eds), Wolin wczesnośredniowieczny. Czesść 2 (318349). Warszawa: Fundacja na Rzecz Nauki Polskiej, Instytut Archeologii i Etnologii PAN, Wydawnictwo TRIO.

Stattler E. (1962). Zagadnienie funkcji sierpów składanych. Slavia Antiqua, 9, 329-334.

Żurowski K. (1974). Zmiękczanie poroży i kości stosowane przez wytwórców w starożytności i we wczesnym średniowieczu. Acta Universitatis Nicolai Copernici. Archeologia, 4, 3-23.

Otrzymano (Received): 11.10.2019; Zrecenzowano (Revised): 25.02.2020; Zaakceptowano (Accepted): 02.03.2020

Author's address:

Mgr Mateusz Osiadacz

Institute of Archaeology and Ethnology

Polish Academy of Science (PAS)

Al. Solidarności 105

00-140 Warszawa

e-mail: mateusz.osiadacz@gmail.com

(iD https://orcid.org/0000-0001-9126-6282 